- at the Nationwide Children's Hospital in Columbus, Ohio. "The manufacturers point their fingers at the FDA, and the FDA points its finger at the manufacturers," she says.

Leber found her own way around the problem. Last year, her lab colleagues hacked into her hospital's machine to upgrade the software that governs resistance categories for carbapenems. Earlier this year the machine identified a case of CRE. The patient was swiftly isolated and an outbreak averted.

Leber worries about smaller clinics that do not have advanced screening equipment, let alone the time and money to update their devices. Meanwhile, CRE cases are spreading out of urban centres. Since the microbes were first detected in North Carolina in 2001, they can now be found in nearly every US state.
Jean Patel, deputy director of the office of antimicrobial resistance at the Centers for Disease Control and Prevention in Atlanta, Georgia, wants screening devices updated faster so that her agency can conduct better surveillance. "It has been a little frustrating to watch how long this has taken." -

Additional reporting by Elizabeth Gibney.

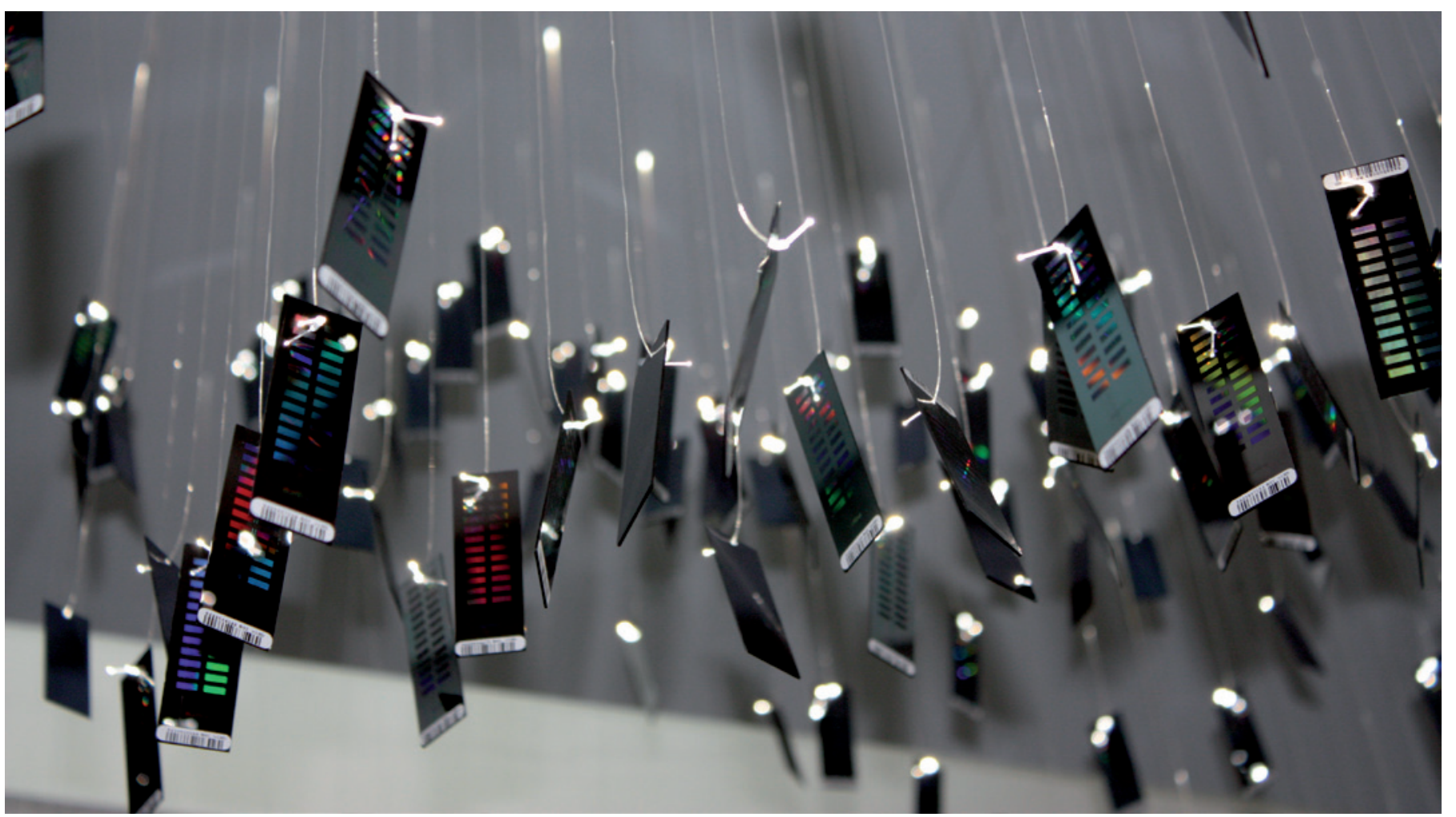

Illuminated microarrays formed part of a display at a medical museum in Copenhagen in 2011.

\title{
Museums hunt for relics
} from genomics' early days

\section{Collectors band together to salvage cast-off equipment.}

\section{BY HEIDI LEDFORD}

$\mathrm{I}$ $\mathrm{n}$ a former envelope factory sits a boxy grey and blue machine the size of an oven - the tenth acquisition this year for a Massachusetts science museum. It is a colony picker, a robotic arm that plucks bacteria from Petri dishes and drops them into a tray with 96 wells, from which DNA is extracted, amplified and sequenced.

At the start of this century, the device powered genomics research at the Whitehead Institute for Biomedical Research in Cambridge, Massachusetts. Now retired, it rests in the warehouse of the Massachusetts Institute of Technology (MIT) Museum, sandwiched between a sewing machine from around the 1920s and an analog computer from the 1950s.

Genomics researchers

\section{$\rightarrow$ NATURE.COM}

For a slideshow of

equipment sought by curators, see:

go.nature.com/05ruqh might find it hard to believe that museum patrons would be interested in paying homage to a piece of lab equipment as pedestrian as a colony picker. Curators of science and technology museums say that is exactly the problem.

"Very few scientists have any idea that they should preserve these things," says Thomas Söderqvist, director of the Medical Museion in Copenhagen. "They just throw them out."

But in the past two years, a confederation of about a dozen science museums has 

coalesced around the need to preserve relics of the genomics revolution, in an effort known as the Museum Genomics Initiative. It was born of a concern that, in a time of shrinking museum budgets, the collection of scientific artefacts was not keeping pace with innovation. This shortcoming has been felt across disciplines, says Simon Chaplin, head of the Wellcome Collection's library of biomedical history in London, which has also joined the initiative. But he says that an effort focused on genomics makes sense because of the field's importance for medicine, appeal to the public and rapid growth since the late 1990s. "There's a real risk that if we don't act quickly, the material legacy of genomics will be lost," he says.

Such was nearly the fate of one of the colony picker's neighbours, a machine with a conveyor belt running along its top. Its job was once to shuttle a colony picker's 96-well trays between stations (each named after a stop on the subway line that runs through Cambridge) to prepare samples for sequencing. John Durant, director of the MIT Museum in Cambridge, came across it about a year ago while rummaging through a storage facility at the nearby Broad Institute.

The machine was slated for disposal, even though it had been used during the peak of the frenzy to sequence the first human genome. "We looked at this thing and said immediately, 'We'll have it'," says Durant.

He likens his job to that of a contemporaryart collector: he has to predict what items will hold value decades from now. Scientific advisers help curators in this assessment. Robert Bud, chief curator of science and medicine at the century-old Science Museum in London - home of 'Baby Blue', a prototype machine for running the polymerase chain reaction to amplify bits of DNA - says that the Museum Genomics Initiative aims to help museums to prioritize and consolidate their efforts by creating a list of pieces recommended for acquisition. Bud declines to name all the items he would put at the top of his own wish list, however: "The moment I say something, it acquires value."

Luckily, unlike contemporary art, cast-off lab equipment rarely comes at a high price. Instead, the cost lies in storage, particularly for large pieces. And if museums want to keep the machines in working order, finding the right consulting technicians and spare parts can be costly, says Heather Erickson, president of the Life Sciences Foundation in San Francisco, California, a non-profit organization dedicated to preserving historical information about biotechnology. (A colony 